\title{
Ensuring that Africa Keeps Rising: The Economic Integration Imperative
}

\author{
Prof. Adrian Saville \& Dr Lyal White ${ }^{1}$
}

\section{Introduction}

The past fifteen years has been witness to a collective rush forward amongst African economies. Though cyclical factors explain some of the economic gains that have been achieved, there is an increasing body of evidence that points to structural factors as being the more powerful force behind 'Africa rising' (Mahijan, 2008). These include sustained higher commodity prices and new sources of demand coming out of rapidly industrialising nations like China and India; material improvements in economic management and policy platforms; debt relief and substantial, sustained debt improvement amongst many economies; and early evidence of Africa's so-called demographic dividend. Notably, in the last ten years a fifth structural factor has begun to make its influence felt: economic integration.

In this regard, economic integration or, more colloquially, "globalisation" takes place through four main channels: namely the flow of goods and services in the form of international trade (T); financial integration via the movement of capital (C); flows of knowledge and information (I); and the movement of people (P), which ranges from tourists to highly skilled workers. The so-called TCIP framework developed by Pankaj Ghemawat (2011a; and 2011b) that flows from this analysis acutely demonstrates how cross-border interactions, economic openness and integration facilitate economic growth and socio-economic advancement.

With respect to Africa, to date researchers have largely sidestepped the key element of economic integration. Arguably, this is because of an uneven understanding of the true role and influence that economic integration plays, compounded by the low level of economic integration historically displayed by African economies, as well as large gaps in our access to data and information that measures such relationships. Moreover, cross-border economic relationships have many dimensions, including their intensity, makeup, geographic nature and degree of sophistication. The multi-dimensional nature of economic integration exacerbates the problem of achieving reliable and robust measures of such relationships (Banerjee and Duflo, 2011, 267).

This article seeks to reduce this gap by assessing the state of Africa's economic integration and the role that integration could play in transforming Africa's surge into sustained, long-term development. The first section explains what we mean by 'economic integration' and considers the evidence for its impacts on nations' economic growth. The second section explores Africa's still-tentative steps towards broader and deeper integration and, in so doing, highlights key inhibitors and enablers. The final section briefly introduces a new instrument for analysing Africa's integration.

\footnotetext{
1 Adrian Saville is Visiting Professor of Economics and Finance at the Gordon Institute of Business Science (GIBS), University of Pretoria and Lyal White is Senior Lecturer and Director of the Centre for Dynamic Markets at GIBS.
} 


\section{Economic Integration: The World Is Your Oyster}

As entrepreneur, industrialist and philanthropist Andrew Carnegie noted more than a century ago in Triumphant Democracy $(1886,13)$ economic integration is a powerful binding force: "A hundred and thirty thousand miles of railways - more than in the whole of Europe - traverse the [United States] country in all directions, and bind the nation together with bonds of steel." This, in turn, led Henry Varnum Poor, the author of Poor's Manual of the Railroads of the United States, to observe in 1888 "... the railroad system may be regarded as the barometer of the entire industrial system." One hundred and twenty years on, Carnegie and Poor's observations about the importance and influence of integration are no less germane.

Integration takes many forms that include a consideration of depth and breadth as well as the geographic nature of economic connections. On this score, 'depth' refers to the extent of economic connections - where a country that has a high degree of connectedness with outside economic partners via trade, capital, information and people (TCIP) flows would be considered to be "deeply" integrated. In measuring 'breadth', a country that has a more diversified portfolio of TCIP flows would be considered to be "broadly" integrated (Ghemawat, 2011a). Dissecting connectedness in this manner is imperative as depth and breadth each play a role in explaining the contribution that economic integration plays in driving socio-economic improvement.

Ghemawat's (2011a) pioneering work on the so-called TCIP framework, which elucidates the strong correlations between integration and economic welfare, provides the foundation for the analysis devoted to Africa in the remainder of this article. The rest of this section considers each of the elements of the TCIP framework and reviews evidence with regard to the impacts of TCIP flows.

\subsection{Trade (T)}

International trade is made up of the flows of goods - so called merchandise trade - and the flow of services. Considering the flow of goods, the theory of international trade identifies six ways in which openness contributes to improvements in economic welfare, namely through additional trade volume; decreased costs of production; differentiation; intensified competition; normalisation of risk; and the generation and diffusion of knowledge. This so-called ADDING value scorecard, an acronym that follows from the first letter of the six items, is briefly discussed below. ${ }^{2}$

The first two components of the ADDING value scorecard relate to economies of scale. In the case of the first component of adding volume, the argument holds that trade liberalisation produces additional trade volumes. This argument is supported by a substantial literature and empirical evidence presented by numerous authors, dating back to Keesing (1967) and, in more recent times, inter alia, Giles and Williams (2000a; and 2000b) Samuelson and Nordhaus (2004), Awokuse (2008), Chan and Dang (2010) and Nain and Ahmad (2010), to mention a few.

The second component acknowledges that the extent of the social welfare contribution of higher trade volume depends heavily on decreased costs that arise through economies of scale and falling production cost. In this regard, the evidence is supportive

2 For further discussion of the gains from opening up presented in this section, see Pankaj Ghemawat's (2011b) World 3.0: Global Prosperity and How to Achieve It, especially Chapter 4. The ADDING acronym is derived from the terms adding volume or growth; decreasing costs; differentiation; intensifying competition and improving industry attractiveness; normalising risk; and generating knowledge and diffusing ideas. 
of the argument that the opening up of an economy and connecting to others has a positive economic effect. Another way in which efficiencies come about with the increased trade that correlates with integration is through investments that are made in cost reduction, such as improving transport infrastructure. Given the considerable infrastructural bottleneck that have hamstrung African trade - discussed later - this is a potentially large contributor to economic welfare in African economies that open up.

The ADDING value scorecard recognises that a third way in which increased trade contributes to economic welfare is by promoting differentiation and improving the available quality of goods. The fourth way more openness can add economic value is by intensifying competition. Economic logic and empirical evidence suggest that openness generally encourages competition which may translate into welfare gains via lower prices and - probably more importantly - greater technical efficiency and faster ongoing productivity growth.

A fifth way that openness can contribute to economic performance is by helping normalise risks. This argument is easily illustrated in the case of volatile commodity markets, such as foodgrains, where there appear to be substantial net gains from further expanding trade in what are generally extremely thin international markets (Ghemawat, 2011a). The sixth way trade can add economic value is by generating and diffusing knowledge faster. In this regard, openness is argued to increase incentives to innovate by expanding markets and permitting quicker diffusion of innovations (Cassiman and Golovko, 2009).

\subsection{Capital (C)}

Cross-border flows of capital (C) form another important pillar of the TCIP framework. In the case of Africa, where domestic savings are particularly low, the role of capital from abroad - or the flow of capital into and between markets - is a vital prerequisite for growth and development.

Whilst the Global Financial Crisis has reminded us of capital market failures and risks, particularly those associated with easily reversible financial flows, or so-called "hot money", this does not change the evidence that "the inflow of foreign direct investment can play a significant role towards economic growth", especially in the case of emerging economies (Heckelman, 2000; Quazi, 2007) .

A large and growing body of evidence shows that the relatively less volatile, more committed categories of foreign direct investment (FDI) and foreign portfolio investment (FPI) make a positive net contribution to emerging economies by helping to fill at least four economic "gaps", namely the savings-investment gap; the export-import gap; the skills, technology and employment gap; and the government revenue-spending gap (Kindleberger, 1972; Dunning, 1988; Todaro and Smith, 2011). Put simply, evidence suggests that international capital flows, by way of direct and spill-over benefits, help the host economy become more competitive and improve socio-economic conditions.

\subsection{People (P)}

Turning to cross-border flows of people, which in the first instance refers to the movement of labour, it is evident that the potential for economic gains is enormous. Indeed, the role that the movement of people between economic regions plays in contributing to economic growth enjoys a long history (see, for instance, Lewis, 1954; and Kuznets, 1955) but is neatly captured in a single observation by Banerjee and Duflo 
(2011, 30) in their seminal work Poor Economics: A Radical Rethinking of the Way to Fight Global Poverty: “... moving can be the first step to changing a family's trajectory”.

This interest in labour mobility has led to estimates that eliminating all restrictions on cross-border labour mobility could double global gross domestic product (GDP) (Hamilton and Whalley, 1984; and Moses and Letnes, 2004). A recent illustration of the contribution that labour mobility can make to economic advance comes from the case of South Korea where, in 2001, the government created a "gold visa" to allow more foreign information technology researchers to work in the country. Campbell $(2012,5)$ notes that this initiative has been one of the central ingredients in South Korea's leapfrogging of many advanced nations.

Of course, as it is with the movement of goods and services (T), the movement of people (P) is dependent on the development of transport infrastructure. Michaels (2008) provides evidence that regions with access to highways that cross borders experience an increase in trade-related activities, especially in services. He also shows that, through increased trade, highways lead to a significant increase in the demand for skilled labour, which has positive social and economic effects. ${ }^{3}$

The movement of people is beyond labour incentives and consumer behaviour. There is a growing interest in social and cultural experiences; and education is increasingly a driver of mobility. More than three million students are studying outside their home countries today - nearly twice the number in 2000 (UNESCO, 2011). For host countries, educating fee-paying foreign students is a lucrative form of income. For students, the value of foreign education is increasing as competition for talent grows and developing local skills - and the best possible education - serves as a competitive advantage (Papademetriou, 2012).

Kennan (2012) concludes that the estimated gains from the free movement of people and more precisely labour - are huge, especially in poorer economies. His research suggests that open borders and the free movement of people could lead to increases in per capita incomes in Ghana, Nigeria, South Africa and Uganda of a weighted average of 160 percent (Kennan, 2012, 21-22).

\subsection{Information and Knowledge (I)}

Globalisation - through strengthened trade links and rising FDI - facilitates catch-up growth as latecomers import and adapt know-how and technology. Derviş (2012) notes succinctly: "It is much easier to adapt technology than to invent it." The contribution that technology makes to economic growth is multi-faceted, but a point of departure is offered by the World Bank (2009), which demonstrates the potential contribution that connectedness makes to economic advance by considering the relationship between telecommunications and economic growth. As Figure 1 illustrates, integration across all of the major telecommunications channels contributes materially to economic growth, but the contribution is particularly marked in the case of low-income economies where, all else equal, integration starts off a lower base. To illustrate, the evidence shows that adding an extra ten mobile phones per 100 people in a typical developing country boosts growth in GDP per person by 0.8 percentage points (World Bank, 2009). More generally, evidence shows that mobile phones facilitate transactions, connect people

\footnotetext{
${ }^{3}$ Further specific evidence on the positive socio-economic effects of the flow of people is provided by Brueckner (2003), who estimates the effect of airline traffic on metropolitan employment in the US, and finds that a ten percent increase in passenger enplanements leads to approximately one percent increase in regional employment.
} 
and have become a principal driver of integration for less developed regions, including Africa.

Figure 1: Growth Impact of Telecommunications ${ }^{4}$

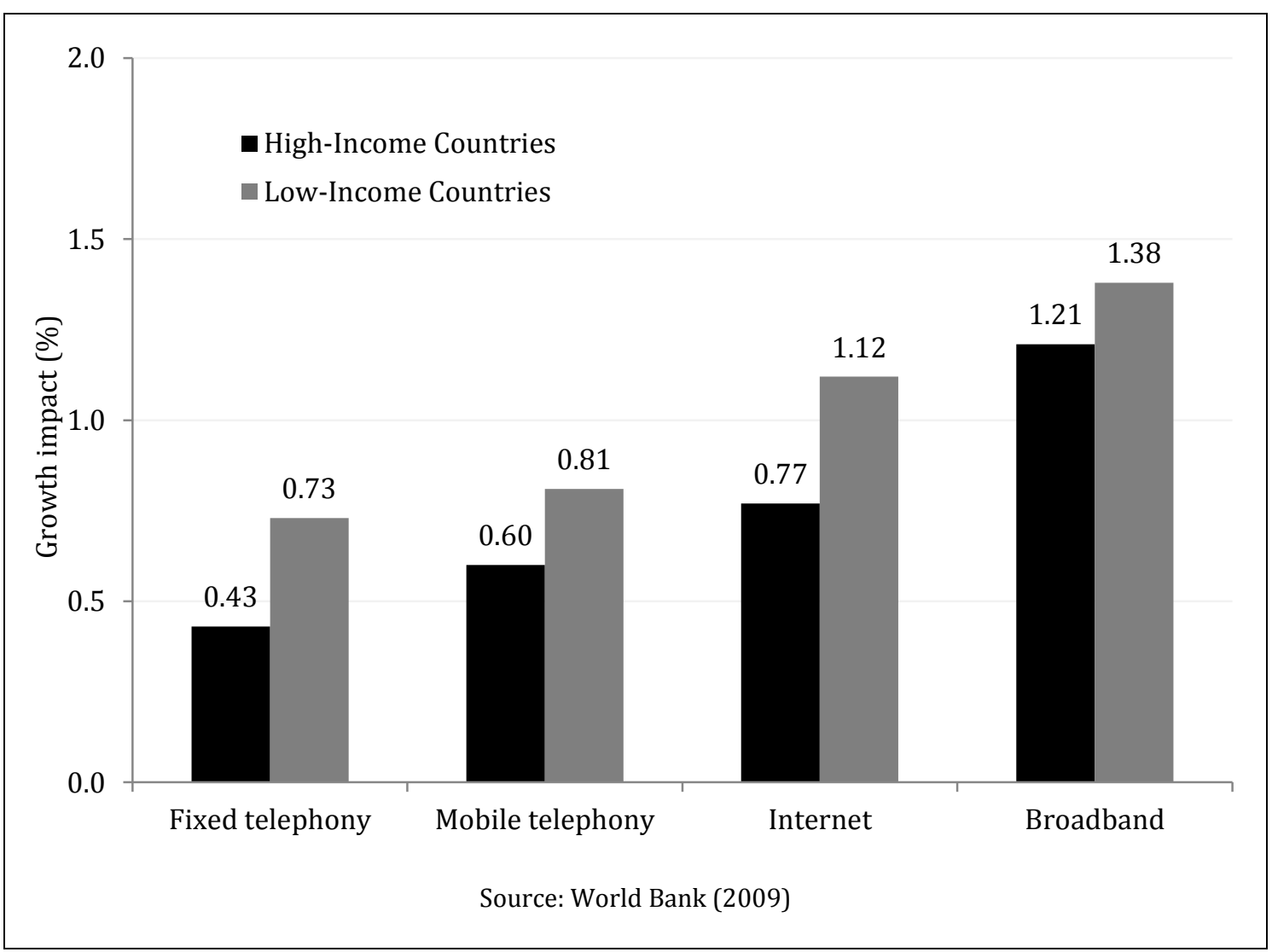

Telecommunications are just one way in which information and knowledge (I) can travel across borders. The flows considered under the elements of trade (T), capital (C) and people (P) all can carry information and knowledge, embodying know-how and know-why, from one country to another, whether embedded in traded products, transferred as a result of FDI or vested in people. But information and knowledge also move across borders in other ways, such as licensing, consulting or piracy. In this regard, the evidence suggests that knowledge and information flows embody strong increasing returns to scale, unlike many other commodities. This is because using information, for example, in one place does not reduce the ability to use it elsewhere.

To demonstrate the magnitude of the gains implied, Ghemawat (2011a) considers a stylised calculation that buckets research and development spending into "domestic" and "foreign" spending. A ten percent increase in cross-border spillovers of research and development spending would overshadow domestic efforts for all but the three top spenders, namely the United States, Japan and China. Arguably more critical is the observation that spillovers have a substantial multiplier effect for countries that are "behind" in terms of spending or are small in economic size. In sum, flows of information and knowledge have potentially substantial, positive impacts on economic welfare.

\footnotetext{
${ }^{4}$ Growth impact of telecommunications measures the GDP percentage point increase due to a ten percentage-point increase in penetration.
} 


\subsection{Addressing Concerns}

The above analysis dwells on the potential gains from increased global integration. As noted by Ghemawat (2011a) it also is important to consider the omitted factors whose inclusion might tilt things the other way if one is to assess net gains rather than just upside potential. The key negative factors identified include market concentration, environmental externalities and risks associated with information imperfections. With respects to risks, for instance, while globalisation in many merchandise categories reduces volatility - the example of food that was cited earlier - large short-term capital flows and foreign debts, influenced by "animal spirits" can be highly pro-cyclical and volatile and, therefore, may need to be managed (Dooley and Hutchinson, 2009; and Ghemawat, 2011b).

Nevertheless, the upshot is clear: concerns about additional cross-border economic relationships and connections pale when the evidence of their benefits is tallied. As Ghemawat (2011b) notes, this does not mean that there are no negative effects of globalisation but rather, if anything, these negative side-effects demand regulation and amelioration. But, in the presence of effective policies that promote functional economic relationships, the arguments and evidence are compelling: the gains from global integration potentially are very large and sustainable. This conclusion is supported below by drawing together the evidence of the economic impact of TCIP flows.

\subsection{Evidence of the Economic Impacts of TCIP}

Using each of the four elements of the TCIP framework, Ghemawat (2011a) constructed an index to measure integration. A strong positive relationship exists between integration and economic welfare, measured by per capita GDP, and the significance of the relationship can be summarised quantitatively by noting that the correlation between economic integration and per capita GDP is 0.58. From this, we can see that higher income countries, or "rich" countries, are more globally connected than poor countries. Thus, measuring integration by way of a TCIP index provides a strong, positive indicator in favour of global integration and improved economic outcomes. Drawn together, the evidence shows that economic openness, or globalisation, together with increasing integration, bodes well for economic prosperity and progressive development.

Of course GDP per capita is just one element of wellbeing. Other, broader and more representative measures of economic welfare can be considered. To this end, the correlation coefficient between the United Nations' Human Development Index (HDI) and TCIP integration is 0.63 , which is even stronger than the 0.58 shown with per capita GDP (Ghemawat, 2011a, 64).

But we need to be careful to recognise that correlation between two variables does not automatically imply that one causes the other. For instance, it might be possible that countries with high per capita incomes, or high human development indices, are the ones that are able to develop connections with the rest of the world, rather than their integration having fostered their richness (Ghemawat, 2011a, 64). That said, the detailed empirical evidence and arguments presented under the TCIP headings offer compelling evidence that there are substantial welfare benefits to be had from global integration and that causality runs from integration to welfare.

These generally positive indications from statistical analysis on the benefits of global integration are backed up by looking at how integration (or the lack of it) has con- 
tributed to individual countries' economic development (Srinivasan and Bhagwati, 1999). ${ }^{5}$ Bangladesh, the Central African Republic and Burkina Faso, which are among the poorest countries in the world, in relative terms, are globally unconnected. Examples such as Hong Kong (China), Singapore, and Luxembourg, which are among the world's richest countries (or territories), suggest openness and a high intensity of crossborder connections are key contributors to economic prosperity (Ghemawat, 2011a).

Against this backdrop, an assessment of Africa's economic integration is presented below which, in turn, holds that Africa stands to gain from a sustained structural benefit brought about by the opening up of African economies to each other and to the world at large.

\section{The Integration Imperative}

Nowhere does Carnegie's observation about the importance of integration, noted above, ring more true than on the African continent, which is on the cusp of its most profound economic take-off in history but is still deeply disconnected in terms of basic infrastructure, including road, rail, information and communication. The African Union (AU) estimates that Africa requires investments totalling $\$ 360$ billion to bring its basic communications and other infrastructure up to speed. The World Bank places this estimate at $\$ 93$ billion per annum (World Bank, 2009). Whilst this is a material physical and financial deficit, integrating Africa and, more specifically, connecting economies and societies across the continent with each other - as much as with the rest of the world is a fundamental prerequisite for the 'Africa rising' trajectory to continue.

Since the turn of the century, the African economy has produced its longest period of sustained economic growth on record. Yet Africa remains the world's least globalised region. It is far less connected to the global economy and to the world economy's value chains than the likes of Asia, Latin America, North America and Europe. Of the world's different regions, Africa also is the least connected internally. The flow of goods, services, capital, people and information between African economies is exceptionally low compared with the intra-regional flows in other parts of the world. Africa's intraregional trade is just 13 percent of its total compared to 32 percent in Latin America, 50 percent in South Asia and over 72 percent in Europe (World Bank, 2012). This is a binding constraint and serious concern for Africa's economic potential. In the same breath, Africa's connectedness is also relevant to economic progress in the world at large. Africa is no longer part of the problem around global economic development, it now is part of the solution and its connectivity is a key factor in contributing to the region's growth as well as augmenting world economic growth.

\subsection{Steps in the Right Direction}

While Africa may be the least globalised region of all, increased economic openness over the past fifteen years has started to contribute substantially toward Africa's economic rise.

Since the late 1990s African economies have become more globally connected. For instance, Africa's exports grew at a rate of 8.8 percent per year between 2000 and 2011, meaningfully above Africa's rate of growth of 5.5 percent over the period, and well in excess of world economic growth of 3.7 percent over the same period. Significantly,

${ }^{5}$ T.N. Srinivasan and Jadgish Bhagwati (1999), in their paper Outward-Orientation and Development: Are Revisionists Right?, advocate the use of case studies on the experiences of individual countries in lieu of cross-country growth regressions. 
exports also are becoming more sophisticated, even to economies that have in recent years come to be considered fiercely competitive. As an illustration, in 2000, African exports to China amounted to $\$ 4$ billion, of which almost the entire value was represented by raw materials and fuel. By 2010, not only had the figure grown substantially, to just under $\$ 115$ billion, but about one-eighth of the value was represented by manufactured goods, machinery and chemicals (China-Africa Economic Trade Cooperation, 2013).

Annual flows of FDI to African countries increased from $\$ 25.0$ billion in the decade of the 1990 s to $\$ 196.6$ billion in the last decade. This constitutes an almost eight-fold increase in FDI, with the number of FDI-funded projects growing at 27.7 percent per year over the period 2003-2011 (Ernst and Young, 2012). Together, these data evidence a persistent, structural opening up of African economies since the turn of the century. In 2000, Africa's total international trade amounted to about 20 percent of GDP. Whilst this is a reasonable figure compared to the global average of 24 percent, at the time, it must also be noted that fuels and primary commodities accounted for about three-quarters of the value of exports in 2000.

Over the past decade Africa has increasingly opened up the spread of exports to international markets. Export volumes have grown at an average 8.8 percent per year since 2000, versus the world average economic growth rate of 3.7 percent. This reflects rising global demand for African products and services. Moreover, given that Africa's export growth exceeded economic growth of 5.5 percent over the period, it follows that exports have become a relatively more important component of the region's economies since 2000 - indicative of the importance of economic openness as a component of sustained economic growth. This is strongly advocated by Dominick Salvatore, who insists that while globalisation often is blamed for economic backwardness, it is countries that have not globalised that are poorest. ${ }^{6}$

New trade partners like Brazil, Russia, India and China - the so-called BRIC economies have increased their trade and investment flows with Africa substantially over the past decade, which has contributed strongly toward African economic growth. In 2001, African economies exported $\$ 24$ billion in goods and services to these four economies; by 2011 , this figure had grown nearly ten-fold to $\$ 194$ billion.

Kenya's experience provides a simple, yet clear, illustration of these phenomena. In 1995 , Kenya's total exports were $\$ 1.5$ billion and the country's five biggest export markets accounted for 55 percent of its exports. Exports were predominantly basic commodities and goods, especially tea and coffee, which together accounted for 37 percent of Kenya's exports in 1995. Such a narrow base in made Kenyan producers overwhelmingly price takers and points to the economy's relatively high vulnerability in international trade relationships at the time. By 2010, Kenya's exports had grown to $\$ 5.6$ billion - a rate of 8.8 percent per year. More importantly, by 2011, Kenya's five biggest export destinations accounted for a more modest 39 percent of exports and basic commodities had fallen substantially, evidenced by the traditional exports of coffee and tea dropping to 25 percent of the total, to be replaced by more sophisticated export products, such as cut flowers ( 9.5 percent of total exports), textiles (4.7 percent), refined oils and petroleum (4.5 percent), and chemicals and allied products (4.0 percent). This is suggestive of rising competiveness and improved industrial health on the part of Kenya.

\footnotetext{
${ }^{6}$ Figure in this section are based on IMF data (2012). Dominick Salvatore is Distinguished Professor at Fordham University in New York City and an authority on international economics. This observation was made in personal communication.
} 
Notably, Kenya's growth in trade and rising sophistication in the country's trade pattern is representative of the trade patterns of a growing number of African economies which, over the past decade, exported more goods of greater diversity and rising sophistication to a growing number of trade partners. However, it must be noted that whilst Africa's international trade patterns evidence increased sophistication, this improvement comes off a very low base of alternative products, and African exports to the new growth drivers - like China, India and Brazil - remain dominated by resources out of the ground.

Still, rising international trade flows also have been met by an increased flow of private capital, which provides further evidence of Africa becoming increasingly open. Again, whilst this improvement comes off a low base, the available evidence shows that increased financial openness corresponds with rising economic welfare. FDI flows to Africa in recent years provide clear support for this argument.

Figure 1: Global and African FDI Trends for New Projects

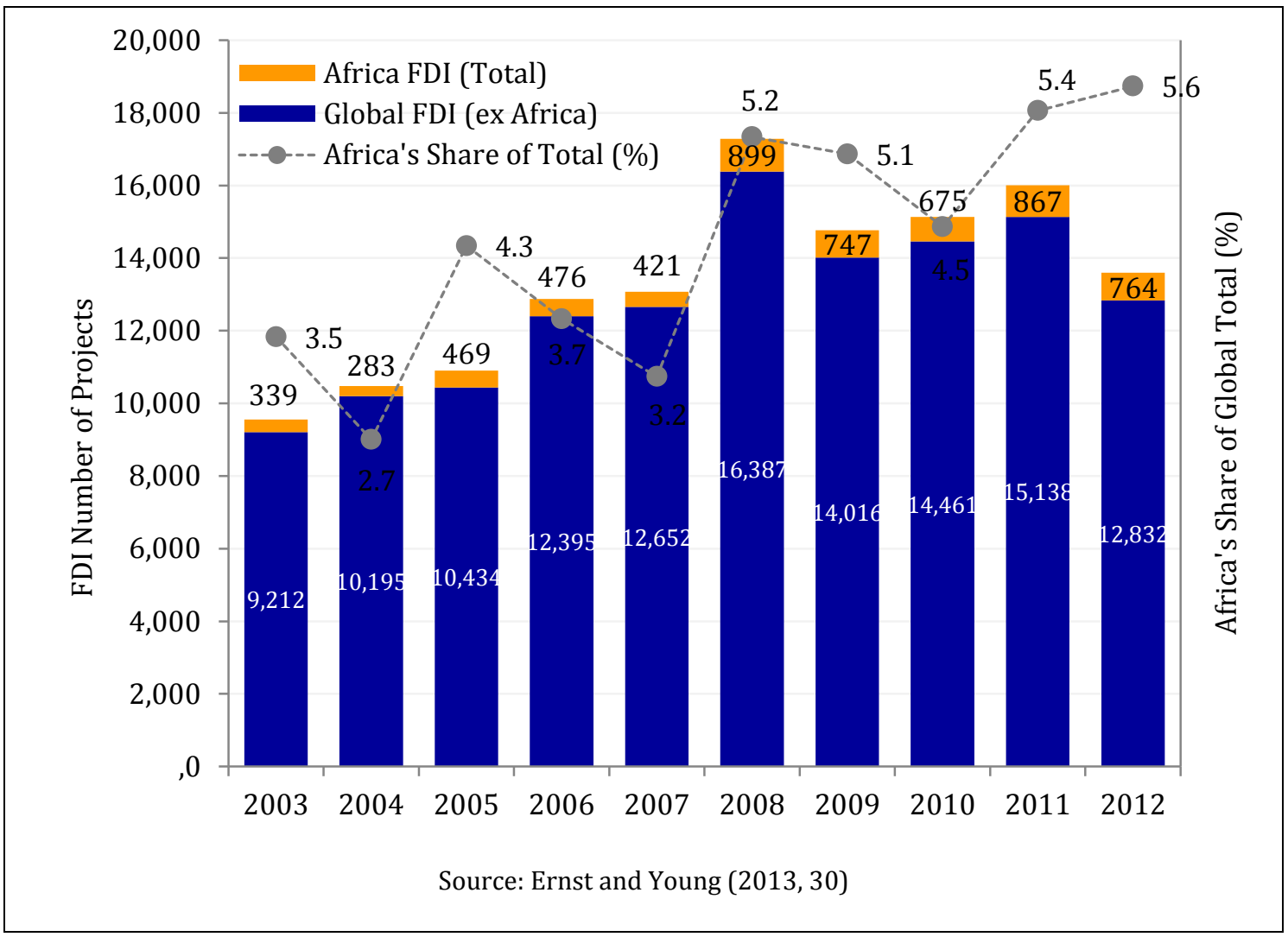

Flows of private capital to Africa have deepened in recent years, as illustrated in Figure 2. FDI flows to Africa are starting also to widen and diversify somewhat from the extractive commodity sectors. For instance, between 2010 and 2012, Chinese investors committed around $\$ 101$ billion to commercial projects in Africa, but less than half of this figure was directly toward extractive industries (Stratfor, 2012). It is true that many of these FDI flows are for mega rail, port, road and energy projects that service the extractive industries, but it is equally clear that Chinese FDI flow, along with others, are financing new areas of industrial activity and that these flows are being directed to other areas of the economy beyond resource extraction. As a case in point, between 2003 and 2011, Zambia received 119 investment projects, with an average project size of $\$ 138 \mathrm{~m}$ (Njau, 2012, 30). However, whereas the Zambian economy is dominated by 
the production of cobalt and copper, of the $\$ 2.4$ billion received between 2003 and 2011, 38 percent of the FDI flows went into manufacturing (Njau, 2012, 31).

This surge in investment in the area of manufacturing is a clear effort to build capacity and competitiveness in response to policy initiatives such as the African Growth and Opportunities Act (AGOA), which grants preferential access to markets in the United States for African manufactured products as an incentive to stimulate export-led growth through manufacturing. ${ }^{7}$

\subsection{Integration Promotes Development}

In considering Africa's increased international trade, growing private capital flows and rising global connectedness we identify the prospect for rising economic integration as a significant and sustainable contributor to economic advance. This in no way ignores or overlooks the negative effects that global economic relations have had on Africa historically, perhaps most potently illustrated by the slave trade (Ferguson, 2002). Nevertheless, the assumption that future global integration will serve as an economic driver as opposed to its historical form of economic retarder (Heldring and Robinson, 2012; Lin, 2012) is well supported by the evidence.

The structural growth factors of external demand, debt relief, policy reform and the demographic dividend as the drivers of economic growth in Africa have received a considerable amount of attention amongst researchers, analysts, strategists, investors and policy makers. The same cannot be said for the role of economic integration in Africa's growth story (Senghor, 2009; World Bank, 2011a and 2011b).

The reason for such scant attention may be that where integration has been considered, the economic emphasis, historically, has been placed on "globalisation", which is defined here as African economies integrating with economies outside of Africa - instead of focusing on the collective potential of the continent. Consequently, deliberations around African economic integration have focused on the influence and impact of relationships with the rest of the world, whilst overlooking the economic potential and role of the neighbourhood. ${ }^{8}$ The positive economic impact of globalisation - for all its challenges is significant. But neglecting the potentially large and sustainable gains in prosperity from greater internal integration is an oversight that needs to be addressed more seriously.

The remarkable successes story of iROKOtv illustrates this argument. iROKOtv was started in 2011 by Jason Njoku's iROKO Partners, one of the fastest growing internet companies in Nigeria. iROKOtv provides an online movie streaming platform and has exclusive rights to distribute Nollywood films. Within six months of launch, iROKOtv had generated three million visits from visitors based in 178 countries and recorded more than 500000 registered users. Key to this success has been internet speeds rising by a factor of 100 between 2008 and 2011, making connectivity viable, with connection costs falling 40 -fold, which have given many Africans an opportunity to connect in this fashion for the first time. In the same breath, more people watch iROKOtv in London than they do in the whole of Nigeria, which suggests that whilst extraordinary potential

\footnotetext{
${ }^{7}$ AGOA is another example from a growing set of policy initiatives of how to incentivise economic diversity and promote openness as a driver of economic growth and development. Initiatives like AGOA serve as important catalysts and stepping-stones toward integration and broader-based globalisation for lessdeveloped African countries seeking access to international markets.

${ }^{8}$ Regional integration in Africa has focused more on political discussions, which have started adopting an economic dimension, but dialogue and negotiations toward wider and deeper integration have traditionally been motivated by confidence building with a political impetus or motivation among member countries.
} 
lies in Africa connecting to the rest of the world, substantial potential equally resides in Africa connecting to itself.

To grasp the vast potential of integration, therefore, it is necessary to accurately assess not just Africa's integration vis-à-vis the global economy but also how connected African countries are to each other.

\subsection{Obstacles to Integrating Globally}

Considering trade ( $\mathrm{T}$ ), first, while Africa has pursued a trade liberalising agenda and a range of free and preferential trade agreements with partners around the world for some time, the movement of goods and services between Africa and the world has been modest, with lacklustre flows lagging other regions. But Africa's poor trade performance is less about policy and preferential access to key markets than about facilitation. It is still significantly more expensive to trade with Africa than with other regions. Enormous efforts are underway to enable the environment for trade by improving infrastructure, minimising costs and ultimately eliminating unnecessary obstacles in an effort to better facilitate flows of goods, in the first instance.

Africa needs to trade and become more integrated in global value chains if it is to harness its natural potential and stimulate wealth and prosperity. This also means growing integration within Africa - to build economies of scale and competitiveness in global markets.

The case of Mercado Comun del Sur or the Common Market of the South (Mercosur), the regional bloc comprising Argentina, Brazil, Uruguay and Paraguay as principal members, is one example of this policy effort. Between 1990 and 1996 intra-regional trade in Mercosur grew a staggering 300 percent while trade with other nations grew 170 percent. In turn, FDI grew ten-fold during the same period (White, 2001). The East African Community (EAC) is the case in Africa that is following a similar trajectory, recognising the importance of scale and competitiveness for its export markets and integrating production and value chains in the sub-region with the intention to access global markets.

Evidence of Africa's low level of financial integration (C) also is readily available. Traditionally Africa's growth and development has relied on flows of development aid from donors or conditional loans from funding agencies or multilateral institutions. While examples of this dependency still exist in some African countries, the story of capital flows in Africa has changed. FDI has increased substantially, from around $\$ 10$ billion in 2000 to over $\$ 45$ billion in 2012 (Ernst and Young, 2013, 31). This is expected to reach $\$ 100$ billion by 2020 , with Africa's high rate of return on investment acting as an ongoing stimulus to capital flows.

While capital flows have diversified in nature and origin - now targeting sectors as diverse as agriculture, manufacturing and tourism alongside resource extraction and infrastructure, from China, Brazil, India and the traditional partners in Europe and the United States - obstacles still hamper flows. Moreover, Africa, by and large, is still severely under-banked and severely under-serviced in the financial sector, which adds constraints around capital flows and business transactions across the continent. But this low level of international financial integration poses an enormous opportunity as business grows and the demand for these services escalates.

Turning to flows of information and knowledge (I), telephone communications are an excellent proxy for the movement of information and ideas, as telephone connections 
provide a platform for the exchange of data and ideas. On this front, Africa has experienced explosive growth. The mobile phone market, for instance, has grown from around zero subscribers in the mid-1990s to 88 million in 2005 and a remarkable 360 million in 2010. The latter figure equates to approximately half of the population (EIU, 2012a, 4), representing a leap in integration in a remarkably short time. Notwithstanding this substantial increase in integration via telecommunications, Africa remains the world's most poorly connected region on this score.

The low level of access to information and knowledge is reiterated by considering internet connectedness. World Bank data show that in 2011 approximately 70 people per 100 are connected via the internet to global information and knowledge flows in high income economies. The figure for middle income economies is 25 , whilst ten people per 100 are connected to the internet in Africa. Moreover, as already highlighted, whilst the growth in connectedness has grown rapidly off a very low base, the scope for connectivity to contribute to socio-economic upliftment is material.

The movement of people (P) in Africa, and people's connectedness to the global economy has been low, historically. But, as is the case with the other three factors of mobility, the mobility of people is rising rapidly off this low base. Examples of this abound. Perhaps one of the best examples is the case, again, of the EAC where the granting of a free movement of people between the member states of Kenya, Uganda, Tanzania, Rwanda and Burundi has proven not only an economic imperative to encourage increased production and competitiveness, but a security imperative associated with the shortage of resources in some locations (like land in Rwanda) and an abundance in others. The elimination of borders prevents overcrowding and allows for a more balanced use of resources on a regional scale.

However, returning to the issue of explaining low people flows, access to transport infrastructure and the efficiency of infrastructure are some of the most important explanatory factors in this regard. For instance, it is estimated that low-cost air travel accounts for less than six percent of passenger miles on the continent (Smith, 2012). Strict visa requirements and border controls are another frustration to trade and the movement of people across borders (Phakathi, 2012). Thus, whilst it may only take 90 minutes to travel by air from Johannesburg in South Africa to Harare in Zimbabwe, it can take another 90 minutes for passengers to clear immigration controls.

The costs to people of moving across borders, extend beyond the opportunity cost of time. Mills (2012) gives the case of the complex Chirundu border post between Zimbabwe and Zambia. A border post as complex as Chirundu has many controls carried out by several authorities, all whom contribute to high total transit times: for northbound traffic, the average time taken for the Zambian Revenue Authority to process a truck and its documents is 17.4 hours, which include time to process documents and inspect loads (Curtis, 2009, xiv). Each control, no matter how small, takes time and can create a bottleneck, to say nothing of additional indirect financial costs.

The above-mentioned examples of Africa's low global integration play an important role in explaining Africa's economic failings. In the same breath, however, it presents a powerful source of sustained structural growth that contributes to the exceptional latent potential of the broad African economy. 


\subsection{Africa's Regional Integration Challenges}

Considering regional integration, more specifically, date for world trade show that roughly two-thirds of trade takes place within continents and half of all trade take place within more narrowly defined sub-regions (Ghemawat, 2011). World Bank (2012) figures indicate that FDI flows take on a similar trend, being heavily influenced by regional patterns. Globally, and contrary to Thomas Friedman's (2004) 9 "flattening of the world" hypothesis, intra-regional trade and investment - or that taking place within regions as opposed to between regions - has been rising at a fast rate. ${ }^{10}$

Figure 3: Intra-African Bilateral Trade from 2002-2010

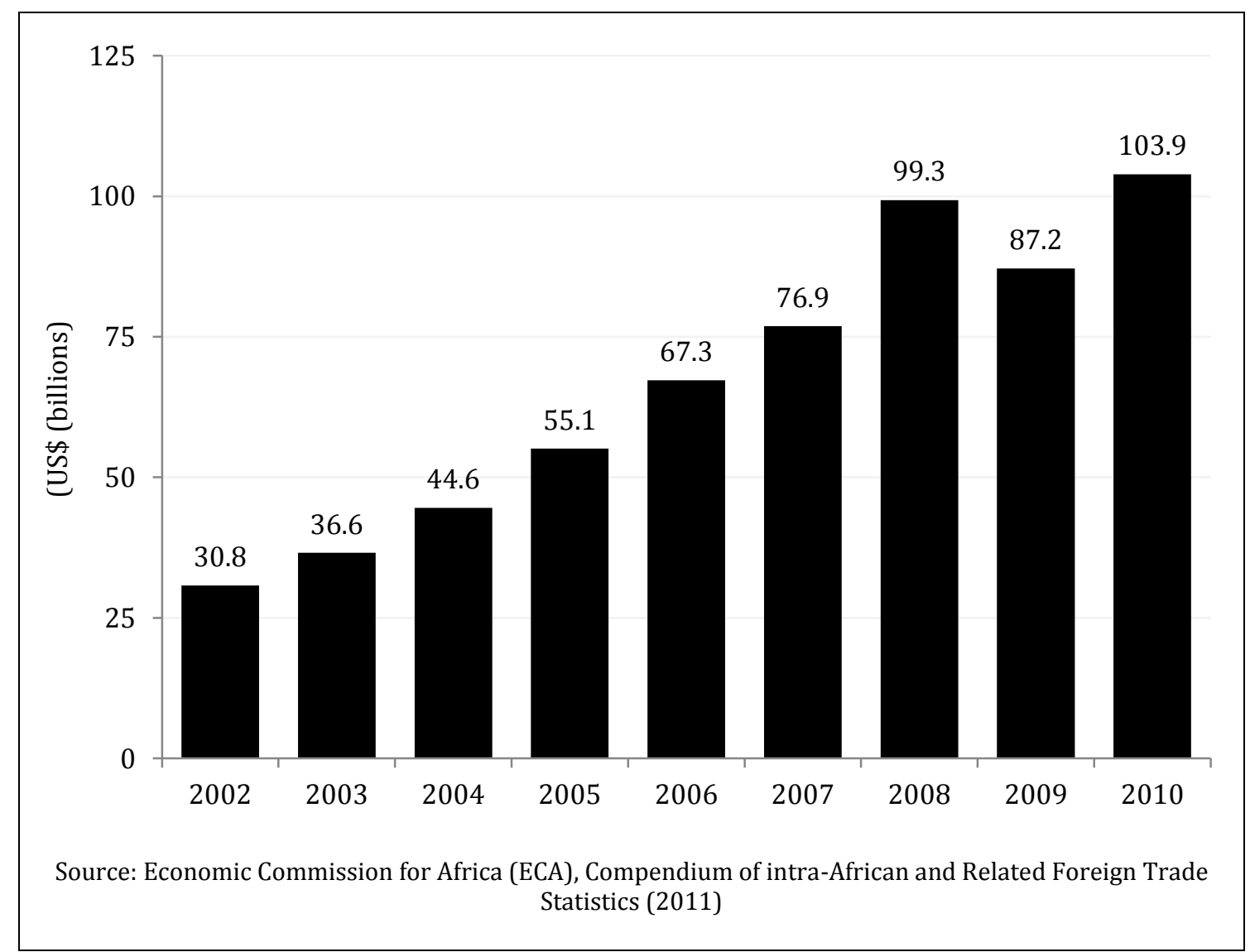

However, whilst the rise in regional trade amongst Africa economies is impressive in nominal terms (Figure 3), the rate of expansion is not much faster than the rate of regional economic growth over this period, and the rise in regional trade has not done any more than match African economies' rise in global trade. As a consequence, in 2011 Africa's intra-regional trade amounted to only 13.1 percent of its total trade - well below the global average (Figure 4).

\footnotetext{
9 There is a long list of authors who have written about this, but Thomas Friedman's (2004) The World is Flat: A Brief History of the Twenty-First Century arguably is the best known amongst these pieces of work. 10 This information is based on the data compiled by Pakaj Ghemawat for the DHL Global Connectedness Index (2011).
} 
Figure 4: Regional Trade Relative to Total Trade by Region (\%) for 2011

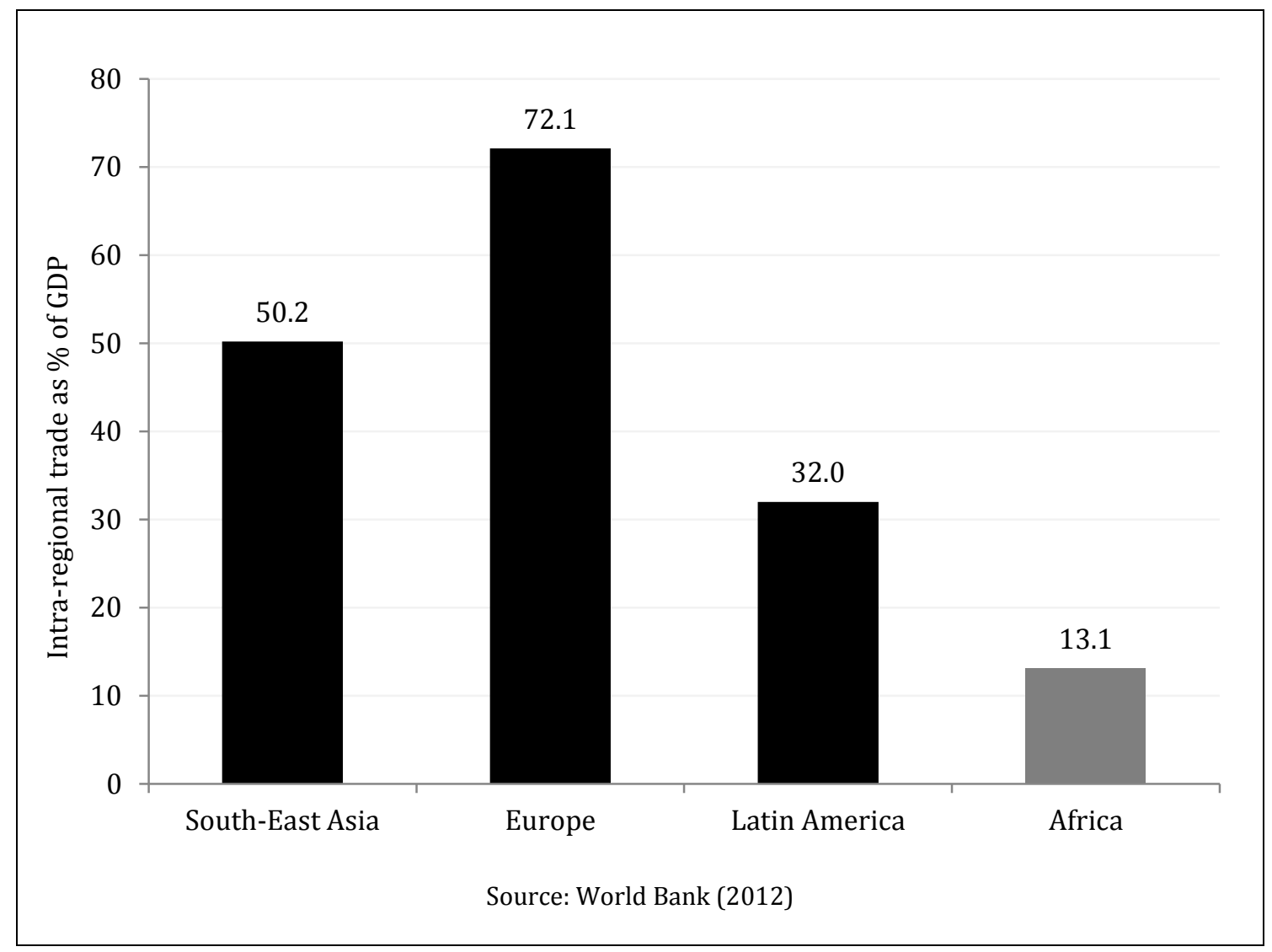

Studies find that two countries can be expected to trade 42 percent more if they share a common language, 47 percent more if they are part of the common trading bloc, 114 percent more if they share a common currency and 188 percent more if one of them colonised the other at some point in history (Ghemawat, 2011b). These linkages are interesting in the context of Africa where intra-regional flows are low and few countries share a common language or culture - but several trading blocs exist.

Capital flows amongst African economies are a rapidly growing phenomenon. Between 2007 and 2011, intra-African FDI into new projects grew at a compound annual rate of 42 percent (Johnson, 2012, 48), but this growth has come off a very low base. As a share of total FDI in the continent, the percentage of intra-African FDI measures about five percent, with the bulk of FDI coming from outside the region. By contrast, the figure for Latin America is ten percent, whilst intra-Asian investment measures 17 percent (Johnson, 2012, 48-51) (Table 1). 


\begin{tabular}{ccc}
\hline \multicolumn{4}{l}{ Table 1: Intra-African Trade and FDI Relative to African Total (\%) } \\
\hline \multicolumn{4}{c}{ Regional Trade (\%) } \\
\hline & & Regional Projects (\%) \\
\hline 2002 & 13.2 & - \\
\hline 2003 & 12.6 & 8.0 \\
\hline 2004 & 12.0 & 6.4 \\
\hline 2005 & 11.5 & 7.7 \\
\hline 2006 & 11.9 & 10.1 \\
\hline 2007 & 11.7 & 8.3 \\
\hline 2008 & 11.8 & 14.8 \\
\hline 2009 & 13.4 & 16.2 \\
\hline 2010 & 13.1 & 16.3 \\
\hline 2011 & - & 16.9 \\
\hline
\end{tabular}

Source: Ernst and Young (2012, 31 and 35)

Experts highlight a set of fundamental reasons for the low level of regional integration, namely low levels of economic and product diversification; historical relationships; poor or inadequate infrastructure; and small markets with low purchasing power. There is little history of trade complementarity between African countries. Infrastructure was originally designed and built to extract resources from the continent to be shipped to other locations and not necessarily to connect one African market to the next.

Considering the issue of economic and product diversification, Angola offers a useful example of a global, rather than regional, focus of African economies. Oil and diamonds make up over 80 percent of Angolan exports and its three principal export partners are China, the United States and the European Union - with the United States absorbing the lion's share of oil exports. Angola's principal import partner is Portugal. Angola's others major import partners include Brazil, the United States, China and South Africa (Saville and White, 2013, 53). Notably, South Africa is the only country from Angola's southern Africa region - and part of the Southern African Development Community (SADC) - that features as one of its main trade partners. The European Union, United States and China have a high demand for petroleum products and have a market of sufficient size and strength to absorb Angola's entire share of oil exports, while Angola is less likely to export petroleum products to, say, Nigeria - which is another large producer of oil in the Africa region.

Whilst the argument has been made that Africa's economic growth is no longer purely resource based, it remains the case that the largest exports from Africa, as we see in the case of Angola, remain natural resources. With low levels of economic and product diversification, the market for exports from African countries are not in other African countries, but rather further afield in markets requiring these resources, but that do not have their own internal supply.

A second factor that contributes to explaining Africa's low regional integration comes from an investigation of historical ties. Again, Angola serves as a useful example to illustrate the case. As a former Portuguese colony, Angola has important trade and investment ties with Portugal and Brazil - another Lusophone country and at one point a colony of Portugal. Angolans traditionally have migrated to Portugal for work or study purposes and Portuguese and Brazilian companies have substantial investments in Angola. The historical relationships are such that Brazilian firms are some of the largest investors in Angola. With well over 100 Brazilian firms operating in Angola, Brazilian products and services are well known, and Angolans frequently travel to Brazil on 
shopping sprees to stock up on goods that are yet to reach African shores. The example is illustrated by Odebrecht, the mega construction company from Brazil, which today is the largest private sector employer in Angola (White, 2010). But the linkages with Brazil stretch well beyond commercial exchanges. Brazilian soap operas are some of the most popular shows on Angolan television and Angolans have developed a strong affinity for Brazilian fashion and pop culture, all of which has translated into a growing connection between the two countries.

A third factor that explains low regional integration is poor or inadequate infrastructure. As noted earlier, Africa has an infrastructure deficit with respect to roads, rail, ports, airports, telecoms, waterways and many other physical contributors to connectivity. This impinges on competitiveness as well as consumer demand, as high trade costs result in higher retail prices and dampen consumers' appetites. To give an idea of the extent of the problem, it is estimated that transportation costs are 136 percent higher in Africa than in other developing regions (Ben Barka, 2012, 4).

The movement of goods and people is not just constrained by poor physical infrastructure. In Africa, the average customs transaction involves 20-30 different parties, 40 documents, 200 data elements (30 of which are repeated at least 30 times) and the rekeying of as much as 70 percent of all data at least once (Ben Barka, 2012, 4). These administrative hurdles escalate trade costs. It is estimated that each day of delay at customs is equivalent to an additional 85 kilometers between the trading countries (see Table 2).

Table 2: Cross-Border Trade Indicators in Selected Sub Regions

\begin{tabular}{|c|c|c|c|c|c|c|}
\hline Region & $\begin{array}{l}\text { Documents } \\
\text { to Export } \\
\text { (Number) }\end{array}$ & $\begin{array}{l}\text { Time to } \\
\text { Export } \\
\text { (Days) }\end{array}$ & $\begin{array}{c}\text { Cost to } \\
\text { Export per } \\
\text { Container } \\
(\$)\end{array}$ & $\begin{array}{c}\text { Documents } \\
\text { to Import } \\
\text { (Number) }\end{array}$ & $\begin{array}{l}\text { Time to } \\
\text { Import } \\
\text { (Days) }\end{array}$ & $\begin{array}{c}\text { Cost to } \\
\text { Import per } \\
\text { Container } \\
(\$)\end{array}$ \\
\hline SADC & 7.3 & 31.2 & 1,856 & 8.4 & 38.0 & 2,273 \\
\hline COMESA & 7.2 & 32.4 & 1,915 & 8.2 & 38.3 & 2,457 \\
\hline ECOWAS & 7.6 & 27.6 & 1,528 & 8.1 & 31.6 & 1,891 \\
\hline CEMAC $^{11}$ & 9.0 & 35.2 & 2,809 & 10.8 & 44.0 & 3,271 \\
\hline Middle East and North Africa & 6.4 & 20.4 & 1,049 & 7.5 & 24.2 & 1,229 \\
\hline East Asia and Pacific & 6.4 & 22.7 & 890 & 6.9 & 24.1 & 934 \\
\hline South Asia & 8.5 & 32.3 & 1,512 & 9.0 & 32.5 & 1,745 \\
\hline Latin America & 7.1 & 19.0 & 1,311 & 7.5 & 22.0 & 1,441 \\
\hline Eastern Europe and Central Asia & 6.4 & 26.7 & 1,652 & 7.6 & 28.1 & 2,548 \\
\hline EU & 4.5 & 11.5 & 1,025 & 5.3 & 12.1 & 1,087 \\
\hline OECD & 4.4 & 10.9 & 1,059 & 4.9 & 11.4 & 1,106 \\
\hline
\end{tabular}

Source: Ministry of Economy and Finance of Nigeria (2011)

Moving capital and people across borders in Africa is also expensive and difficult. In the case of capital, drawing on World Bank data, Chandy, Dervis and Rocker $(2013,19)$ find the cost of sending money across the Tanzania-Kenya border is nearly ten times the price of sending money from the United Kingdom to Pakistan. In the case of Tanzania and Rwanda the cost is eight times the price of moving money between the United Kingdom and Pakistan, and the multiple for South Africa and Mozambique is six times. These exorbitant costs of moving funds across borders act as a direct challenge to financial integration. Much the same could be said for Africa's often-prohibitively high air travel costs.

11 The aggregate data for the CEMAC region cover all member states with the exception of Chad. That is, the data include Central African Republic, Congo, Equatorial Guinea and Gabon. This is because of a lack of accurate data and information for Chad. 
Hampered by infrastructure that was designed by former colonial powers to efficiently move resources out of Africa rather than within Africa, infrastructure - comprising improved processes as much as it includes physical infrastructure - geared toward intra-regional flows will go a long way in connecting African countries with each other and from there, through their coastal ports to global markets. One example of the benefits that flow from removing obstacles to regional integration comes from the West African Economic and Monetary Union (also known as UEMOA from its name in French, Union économique et monétaire ouest-Africaine). Due to the implementation of various "easy-to-fix" initiatives, trade inside this region has grown by 40 percent in ten years, well above the average for the continent and now also highest in relative terms for the continent (Ben Barka, 2012, 3).

The above evidence of exceptionally low levels of intra-Africa flows and regional integration, like the continent's low level of global integration, is an important explainer of Africa's poor economic record whilst, simultaneously, pointing to the substantial economic potential that resides in the prospect of African economies connecting to each other via regional relationships and economic assimilation.

\section{Conclusion: Analysing and Promoting a More Integrated Continent - The Visa Africa Integration Index}

Africa is becoming more connected, but borders and distance continue to matter a great deal in hampering and retarding economic integration. This is a notable structural factor because, besides the enormous dormant opportunities that lie in African consumer and labour markets, improved connectivity between African countries and a regionally integrated continent is a key imperative for scale and competitiveness as Africa globalises.

The preceding analysis highlights the need for a contemporary measure of integration across the continent, which allows for a dynamic study of the evolution of economic integration and how integration contributes to Africa's improving socio-economic prosperity. This lacuna was the impetus behind the Visa Africa Integration Index, a new instrument developed by the authors which, it is hoped, will represent a significant contribution to existing toolkits designed to help us understand the changes, challenges and opportunities presented by Africa's economic leap forward.

Drawing on the seminal work of Pankaj Gemawhat, 12 the Visa Africa Integration Index and this article makes a new - and arguably important - contribution to our understanding of the nature and extent of economic relationships amongst some of Africa's largest economies. Amongst other things, by developing the index we achieve a sophisticated measure of economic integration that incorporates the four pillars of economic connectedness, namely trade, capital, information and people (TCIP) flows, described earlier in the paper. ${ }^{13}$ In addition to measuring these pillars at the country level, the granularity of the data to which we have access allows us the ability to

\footnotetext{
12 The Visa Africa Integration Index owes a large debt to Pankaj Ghemawat (2011a; and 2011b) with regard to understanding global connectedness, its measurement and its impacts, specifically contribution to the debate on global connectedness by way of the construction of the DHL Global Connectedness Index.

13 This TCIP model assigns a numeric value to the level of integration, with the global median score being 100. The West Africa cluster Visa Africa Integration Index score: Nigeria, 40.6; and Ghana, 52.1. The Southern Africa cluster score: South Africa, 63.3; Mozambique, 42.4; Zambia, 35.8; Zimbabwe, 31.1; and Angola, 28.8. The East Africa cluster score: Kenya, 53.9; Uganda, 48.7; Rwanda, 47.3; and Tanzania, 45.3.
} 
measure economic integration at global and regional levels, and also to measure the depth and breadth of these relationships.

Over the course of the twentieth century the African economy failed to advance meaningfully, with little or no economic growth or progress enjoyed by Africans. In 1900 , income per person for the continent stood at $\$ 601$, equivalent to 50 percent of the global average of $\$ 1,261$ at that time. ${ }^{14}$ By 2000 , global per capita income had grown in real terms at 1.6 percent per year to reach $\$ 6,038$. Yet Africa had failed to keep up, with income per person growing at just 0.9 percent a year, measuring $\$ 1,447$ per person at the end of the period. Moreover, almost all of this growth was explained by a handful of countries. By many measures and standards, the twentieth century was by and large a lost century for Africa.

The much-vaunted narrative of 'Africa rising', which has captured the business world's imagination in the past half-decade or so, and which has been prominently presented in recent cover stories by Time Magazine and The Economist, is based in significant part on profound structural changes to the way African economies function. This paper has focused on one of the least examined - and least understood - facets of this structural transformation, namely economic integration. Yet Africa's transformation is far from complete. As a senior African official said recently at a private high-level seminar, 'Africa may have reached an economic turning point. But that is not the same as reaching the tipping point to inclusive, sustainable growth. Moving from turning point to tipping point is now Africa's challenge'. 15

Of the numerous factors that are likely to define Africa's development, this paper has highlighted the myriad ways deeper and broader integration of African economies amongst themselves and with the rest of the world - could have a catalytic impact on the continent's future prosperity and avoid the reversals suggested in the official's salutary warning. The construction of the Visa Africa Integration Index, briefly alluded to above, stemmed from the recognition that research into the benefits of African integration was poorly served by existing analytic tools.

The good news for Africa is that, whilst coming off a modest base, the continent's economies are rising in terms of the degree and sophistication of economic integration. Given the rapidly improving economic environment and composition, the socio-economic gains that come with rising integration - especially when it entails more connectedness with neighbours - should translate into rising investment opportunities and prospects for new business relationships across the continent. The less good - or perhaps more challenging - news for Africa is that it still has a long way to go before catching up with the rest of the world. The evidence presented in this study powerfully underlines the need for African countries to bridge the gap.

\section{References}

Antweiler, W. and Trefler, D. (2002), Increasing Returns and All That: A View from Trade. American Economic Review, Vol. 92(1): 93-119.

\footnotetext{
14 All references to \$ infer United States dollar, unless otherwise specified.

15 At the Brenthurst Foundation's Tswalu Dialogue, 22-24 November 2013, see http://transatlantic.saisjhu.edu/events/2013/Atlantic\%20Basin\%20Initiative_DR/2014/Atlantic\%20Basin\%20Initiative\%20Tswa $\underline{\text { lu\%20Summary\%20final.pdf }}$
} 
Awokuse, T.O. (2008), Trade Openness and Economic Growth: Is Growth Export-Led or Import-Led? Applied Economics, Vol. 40(2): 161-173.

Banerjee, A.V., and Duflo, E. (2012), Poor Economics: A Radical Rethinking of the Way to Fight Global Poverty. New York: Public Affairs.

Ben Barka, H. (2012), Border Posts, Checkpoints, and Intra-African Trade: Challenges and Solutions. African Development Bank: Tunis, Tunisia.

Brueckner, J. (2003), Airline Traffic and Urban Economic Development, Urban Studies, Vol. 40(8): 1455-1469.

Business Day (2012), Angola's Rich-Poor Schism, Business Day, 30 August 2012.

Campbell, J.R. (2012), Building an IT Economy: South Korean Science and Technology Policy, Brookings Institution Issues in Technology Innovation, No. 19: September.

Carnegie, A. (1886), Triumphant Democracy. Originally published by DoubleDay \& Co. Republished in 2005 by Cosimo: New York

Cassiman, B. and Golovko, E. (2009), Productivity of Catalan Firms: International Exposure and (Product) Innovation, in Ghemawat, P. and Vives, X. (eds.), Competitiveness in Catalonia prepared for Foment del Treball, May 2009.

Chan, K.S. and Dang, V.Q.T. (2010), Multilateral Trade and Export-Led Growth in the World Economy: Some Post-War Evidence, Empirical Economics, Vol. 38(3): 689-703.

Chandy, L., Dervis K. and Rocker, S. (2013), Clicks into Bricks, Technology into Transformation, and the Fight against Poverty. Brookings Blum Roundtable 2012: Brookings Institution.

China-Africa Economic Trade Cooperation (2013), 2013 China-Africa White Paper. Information Office of the State Council: People's Republic of China.

Curtis, B. (2009), The Chirundu Border Post: Detailed Monitoring of Transit Times. World Bank: Washington, D.C.

Derviş, K. (2012), Convergence, Interdependence, and Divergence, Finance and Development, Vol. 49, No. 3.

Donaldson, D. (2010), Railroads of the Raj: Estimating the Impact of Transportation Infrastructure. Massachusetts Institute of Technology, mimeo.

Dunning, J.H. (1988), Explaining International Production. London: Hymer, Unwin.

Duranton, G., Morrow, P. and Turner, M. (2011), Roads and Trade: Evidence from the U.S.. University of Toronto, mimeo.

Duranton, G. and Turner, M. (2012), Urban Growth and Transportation, Review of Economic Studies, Vol. 01: 1-36.

Economic Commission for Africa (2010), Assessing Regional Integration in Africa IV: Enhancing Intra-African Trade. United Nations Economic Commission for Africa: Addis Ababa.

(2011), Governing Development in Africa: The Role of the State in Economic Transformation. United Nations Economic Commission for Africa: Addis Ababa.

Economist, The (2000), The Hopeless Continent. The Economist, 13 May 2000.

Economist, The (2009), Special Report on Telecoms in Emerging Markets: Mobile Marvels. The Economist, 24 September 2009.

Economist, The (2013), Aspiring Africa. The Economist, 2 May 2013.

Economist Intelligence Unit (EIU) (2012a), Into Africa: Institutional Investor Intentions to 2016. An Invest AD report written by the Economist Intelligence Unit. (2012b), South Korea Looks to Boost Foreign Direct Investment, Economist Intelligence Unit, 25 September 2012.

Ernst and Young (2012), Building Bridges: 2012 Attractiveness Survey. Ernst and Young: Emerging Markets Center.

(2013), Getting down to Business: 2013 Attractiveness Survey. Ernst and Young: Emerging Markets Center. 
Ferguson, N. (2002), Empire: The Rise and Demise of the British World Order and the Lessons for Global Power. London: Allen Lane.

Foster, L., Haltiwanger, J. and Syverson, C. (2008), Reallocation, Firm Turnover, and Efficiency: Selection on Productivity or Profitability? American Economic Review, Vol. 98(1): 394-425.

Franzoni, C., Scellato, G. and Stephan, P. (2012), The Mover's Advantage: Scientific Performance of Mobile Academics, NBER Working Paper No. W18577, November 2012.

Friedman, T. (2004), The World is Flat: A Brief History of the Twenty-First Century. Farrar, Strauss and Giroux: New York.

Ghemawat, P. with Altman, S. (2011a), DHL Global Connectedness Index 2011: Analyzing Global Flows and their Power to Increase Prosperity. Deutschepost DHL: Bonn, Germany.

Ghemawat, P. (2011b), World 3.0: Global Prosperity and How to Achieve It. Harvard Business Press: Boston, Massachusetts.

Giles, J.A. and Williams, C. L. (2000a), Export-Led Growth: A Survey of the Empirical Literature and Some Non-Causality Results (Part 1), Journal of International Trade and Economic Development, Vol. 9(3): 261-337.

(2000b), Export-Led Growth: A Survey of the Empirical Literature and Some Non-Causality Results (Part 2), Journal of International Trade and Economic Development, Vol. 9(4): 445-470.

Hamilton, B. and Whalley, J. (1984), Efficiency and Distributional Implications of Global Restrictions on Labour Mobility: Calculations and Policy Implications, Journal of Development Economics, Vol. 14(1-2): 61-75.

Heckelman, J.C. (2000), Economic Freedom and Economic Growth: A Short Run Causal Investigation, Journal of Applied Economics, Vol. 3(1): 71-91.

Heldring, L. And Robinson, J.A. (2012), Colonialism and Economic Development in Africa, NBER Working Paper Series No. 18566, www.nber.org/papers/w18566.

Johnson, L. (2012), Intra-African Investment: A Pressing Issue, African Investor, Vol. $10(6): 48-51$.

Keesing, D.B. (1967), Outward-Looking Policies and Economic Development, Economic Journal, Vol. 77(306): 303-320.

Kennan, J. (2012), Open Borders. NBER Working Paper No. 18307. August 2012

Kindleberger, C.P. (1972), Direct Investment in Less Developed Countries. In: Di Marco, L.E. (ed.) International Economics and Development. New York: Academic Press.

Kuznets, S. (1955), Economic Growth and Income Inequality, American Economic Review, Vol. 45(1): 1-28.

Lewis, W.A. (1954), Economic Development with Unlimited Supplies of Labour, Manchester School, Vol. 22(2): 139-191.

Lin, J.Y. (2012) The Quest for Prosperity: How Developing Economies Can Take Off. Princeton University Press: Princeton.

Mahijan, V. (2008), Africa Rising: How 900 Million African Consumers Offer More Than You Think. Prentice Hall: Upper Saddle River, New Jersey.

Michaels, G. (2008), The Effect of Trade on the Demand for Skill: Evidence from the Interstate Highway System, Review of Economics and Statistics, Vol. 90(4).

Mills, G. (2012), The Long and Bumpy Road to Jobs and Prosperity in Southern Africa, Sunday Times, 16 September 2012.

Moses, J.W. and Letnes, B. (2004), The Economic Costs to International Labor Restrictions: Revisiting the Empirical Discussion. World Development, Vol. 32(10): 1609-1626.

Nain, M. Z. and Ahmad, W. (2010), Export-Led Growth Hypothesis in India: Some Further Evidences. IUP Journal of Monetary Economics, Vol. 8(3): 69-82. 
Njau, B. (2012), Resource-Rich Zambia Hopes Diversity Will Bring Prosperity. FDI Intelligence, June 2012.

Opera Software (2012), State of the Mobile Web. Accessed via http://business.opera.com/smw/2010/02/.

Papademetriou, D.G. (2012), Migration Meets Slow Growth, Finance and Development, Vol. 49, No. 3.

Phakathi, B. (2012), SA's Visa Requirements Harm Trade, Business Day, 27 July 2012.

Quazi, R. (2007) Economic Freedom and Foreign Direct Investment in East Asia, Journal of the Asia Pacific Economy, Vol. 12(3): 329-344.

Saville, A. and White, L. (2013), Realising Potential: Connecting Africa. Working paper. Available at bit.ly/17j20yH.

Senghor, J.C., Ashurst, M., Bhalla, J., O'Brien, A., Paice, E. and Rawlinson, A. (2009), Going Public: How Africa's Integration Can Work for the Poor. Africa Research Institute: London.

Smith, N. (2012), Airbus Sees Doubling of Aviation in Africa, Business Day, 14 September 2012.

Stratfor (2012), Chinese Investments in Africa, Stratfor Global Intelligence, August 2012.

United Nations Educational, Scientific and Cultural Organization (UNESCO) Global Education Digest 2011, Institute for Statistics, UNESCO: Montreal.

White, L (2010), “Understanding Brazil's new drive for Africa." In South African Journal of International Affairs, Vol.17, No. 2, August 2010 (221-242).

White, L (2013), "Emerging Powers in Africa: Is Brazil any different?" In South African Journal of International Affairs, Vol. 20, No. 1 (117-136).

White,L (2001), "South-South Co-operation: The Case of SADC and Mercosur." MA Thesis, University of Stellenbosch.

World Bank (2009), Information and Communications for Development: Extending Reach and Increasing Impact. World Bank: Washington, D.C

World Bank (2011a), Africa Development Indicators: 2011. World Bank: Washington, DC. (2011b), Africa's Future and the World Bank's Support to It. World Bank: Washington, DC.

Young, A. (2012), The African Growth Miracle. NBER Working Paper No. W18490, October 2012. 